\title{
An Evaluation of Effective Communication Skills Coursebook
}

\author{
Shameem Ahmed \\ Centre for the Promotion of Knowledge \& Language Learning, University Malaysia Sabah-KAL, Malaysia \\ E-mail: shameem@ums.edu.my
}

Doi:10.7575/aiac.alls.v.7n.3p.57

Received: $15 / 01 / 2016$

URL: http://dx.doi.org/10.7575/aiac.alls.v.7n.3p.57

Accepted: 28/02/2016

\begin{abstract}
In Communicative Language Teaching situation, role of material is not only important but also inevitable. In the traditional context of English teaching textbooks are considered the main source of materials. This paper will provide an evaluation of Effective Communication Skills (ECS) coursebook that has been introduced as a pilot project implemented in 2011 by the Ministry of Higher Education, Malaysia. For the current study, data has been collected on the basis of materials study, and questionnaires. The qualitative analysis has been conducted with a total sample of around 214 students, and 3 instructors. The results show that in spite of some shortcomings, there is a general satisfaction about this textbook as it is exclusively produced by the local experts for the tertiary level. The study concludes with suggestions and recommendations for the improvement of the Effective Communication Skills.
\end{abstract}

Keywords: Coursebook evaluation, communicative English, Pilot Project, ECS

\section{Introduction}

\subsection{Materials}

Longman Dictionary (2010) defines a coursebook as "in language teaching, a book (usually as part of a series of books) that contains all the materials necessary for a particular type of language learner at a particular level (e.g. intermediate level adults). Such a book is typically based on an integrated or multi-skills syllabus i.e. one that contains sections on grammar functions, vocabulary, listening, speaking, reading and writing." Hutchinson (1987) opines that materials are not merely the everyday implements of the language instructor; they are an epitome of the aims, values and methods of the particular teaching/learning situation. As a result, the selection of materials probably embodies single most important decision that the language instructor has to make.

According to Tomlinson (2005), 'materials' are inclusive of anything which can be used to facilitate the teaching and learning of a language. They can be linguistic, visual, auditory or kinaesthetic, and they can be presented in print, through live performance or display, or on cassette, CD-ROM, DVD or the internet. They can be instructional, experiential, elicitative or exploratory while informing learners about the language, providing experience of the language in use, stimulating language use or helping learners to make discovery about the language for themselves.

McGrath (2013) reflects materials as: a textbook, produced by a commercial publisher, a ministry of education or a large institution usually accompanied by some combination; Commercial materials that is not provided as part of the textbook package; Teacher-prepared materials selected by or devised by the teacher or a group of teachers working together; Some teachers will also enlist the aid of learners to supply or create materials. He further contends that materials or coursebook tends to be the foundation for a language course since they are so popular. According to him, in spite of shortcomings coursebook includes the following advantages: reduce time for lesson preparation; provide a visible, coherent programme of work; provide support; a convenient resource for learners; make standardized instruction possible; visually appealing, cultural artifacts; contain 'a wealth of extra material' etc.

According to Harmer (2007) coursebooks have the following advantages: sensibly prepared to offer a coherent syllabus, adequate language control, motivating language use with supplementary materials; often nicely presented; a source of some dependable materials under pressure; have got detailed teacher's guide providing not only lesson plans but also suggestions and alternatives, extra activities and resources; adoption of a new coursebook offers a great stimulus for methodological development.

Various other writers have pointed to particular functions fulfilled by textbooks. They play a major role in supporting and complementing the teacher, as well as supporting the learner. As a result, the most commonly found elements in ESL/EFL classrooms around the world are teachers, learners and textbooks. Since textbook or materials are such a key component of language classrooms, their suitability and effectiveness deserve critical attention (McGrath 2013).

Choosing course materials require critical consideration that can be undertaken in two stages in evaluating the relevance of a book to a particular group of students. The first stage assesses the book contents with its stated aims that enables evaluation of the extent to which a book fulfills its own aims and is therefore reliable in carrying out its undertakings to the learners. The second stage assesses the book against the needs and context of the intended learners, i.e. are the materials appropriate and effective in helping learners to acquire English? It would be useful to list some key categories 
for evaluation and then list questions for each category: categories in accordance with learner factors, institutional setting, and sociocultural context. There are a number of such checklists available for textbook evaluation. Among these key are: the view of language; the view of language learning; learners; the view of education; the environment of learning etc. (Hedge, 2003).

Graves (2003) observes that a coursebook is a learning tool shared by teachers and learners that can be used in systematic and flexible ways. In order to use a coursebook systematically and flexibly, it is important to understand how it is put together and how it can be adapted to meet the needs of the particular learners. What happens in the classroom fills out and transforms the visible course outline into learning experiences for the students.

\subsection{Evaluation}

Hutchinson (1987) states that materials evaluation plays such a vital role in language teaching that its possibility for influencing the ways teachers functions is quiet significant. Materials evaluation could be a two-way process which allows teachers not only to select a material, but also to develop their perception of their own teaching/learning situation. Materials evaluation is basically a matching process in which the necessities and expectations of a specific teaching-learning context are matched to existing resolutions. Effective materials evaluation process may well serve in an awareness building role where materials and teaching/learning situations help to inform one another. This matching process has four stages: define the criteria on which the evaluation will be based; analyse the nature and underlying principles of the particular teaching/learning situation; analyse the nature and underlying principles of the available materials and test the analysis in the classroom; and finally compare the findings of the two analyses.

According to Tomlinson (2011) materials evaluation is "the systematic appraisal of the value of materials in relation to their objectives and to the objectives of the learners using them. Evaluation can be pre-use and therefore focused on predictions of potential value. It can be whilst-use and therefore focused on awareness and description of what the learners are actually doing whilst the materials are being used. And it can also be post-use and therefore focused on evaluation of what happened as a result of using the materials". Actually, materials evaluation is a procedure that involves measuring the value or the potential value of a set of learning materials. It involves making judgments about the effects of the materials on the people using them. Tomlinson (2005) opines that materials evaluation tries to measure some or all of the following components: appeal of the materials to the leaners; credibility of the materials to the learners, teachers and administrators; validity of the materials; reliability of the materials; ability of the materials to interest the learners and the teachers; ability of the materials to motivate the learners; value of the materials in terms of short-term learning; value of the materials in terms of long-term learning; learners' perception of the value of the materials; teachers' perception of the value of the materials; assistance given to the teachers in terms of preparation, delivery and assessment; flexibility of the materials; contribution made by the materials to teacher development; match with administrative requirements.

Rubdy (2005) proposes a static versus dynamic model of material evaluation. The static mode of evaluation involves analyzing the texts, tasks and activities in terms of pedagogical and psychological validity; whereas the dynamic mode contains a more in-depth analysis requiring 'look beneath the surface' to discover thorough a series of subjective judgments and inferences i.e. through process and content validity.

Roberts (1996) suggests material evaluation as a total process. This total process of evaluation entails roughly three stages: decision stage 1,2,3. Decision stage 1 involves design, writing and initial execution i.e. pre-publication; decision stage 2 contains pencil and paper evaluation i.e. post-publication; decision stage 2 covers summative evaluation through both teachers' and learners' experiences with the materials i.e. post-publication.

\subsection{Materials Adaption}

Murray and Christison (2011) state that “...textbooks do not always drive the teaching-learning process, but rather provide a scaffold on which teachers and learners can build. Because textbooks are mostly written for a wide range of learners, teachers find they need to adapt a textbook that they or their institutions have chosen. This may include making changes to activities and texts in the textbook or supplementing the textbook with additional materials, either from other sources or written by the teacher". In this context Richards (2002), states that commercial textbooks can hardly be used without some adaptation to make them more suitable for the particular context of their usage. This adaptation may take in the following forms: modifying content, adding or deleting content, reorganizing content, addressing omissions, modifying tasks, extending tasks etc. Language teachers need to build this essential skill of adapting commercial coursebooks in the above-mentioned ways.

A coursebook is a learning tool shared by teachers and learners that can be used in systematic and flexible ways. In order to use a coursebook systematically and flexibly, it is important to understand how it is put together and how it can be adapted to meet the needs of the particular learners. What happens in the classroom fills out and transforms the visible course outline into learning experiences for the students. They're written for a generalized target group. No book can meet all the needs and interests of each group of learners that uses it. For this reason, a coursebook must be adapted to the particular group of learners. A coursebook is not an inflexible document; it is a learning tool that is used by learners and teachers. The decisions about what to "select, adapt, reject and supplement" depend on who the learners are (age, interests, purposes for studying and language level), what the institution emphasizes, the available resources, duration or time frame, and what is important (Graves, 2003). Acklam (1994:12 as cited in Graves 2003) suggests the following acronym for adapting a coursebook: "SARS." SARS stands for S: select parts of the coursebook you definitely want to keep; A: adapt parts of the coursebook you want to keep, but need to change to make them more 
suitable for students, and adjust with teaching style; R: reject parts definitely want to leave out; S: supplement means necessary elements to bring to the coursebook to fulfill the requirements of the overall syllabus and to respond to the needs of students. In this connection, Harmer (2007) is of the opinion that many teachers want to use coursebooks as a kind of facilitator for their lessons, rather than as a manual to be mindlessly followed, i.e. they use the coursebooks as a main basis for lessons while they have the option to decide when and how to use its essential parts. These options could be summarized in the following figure:

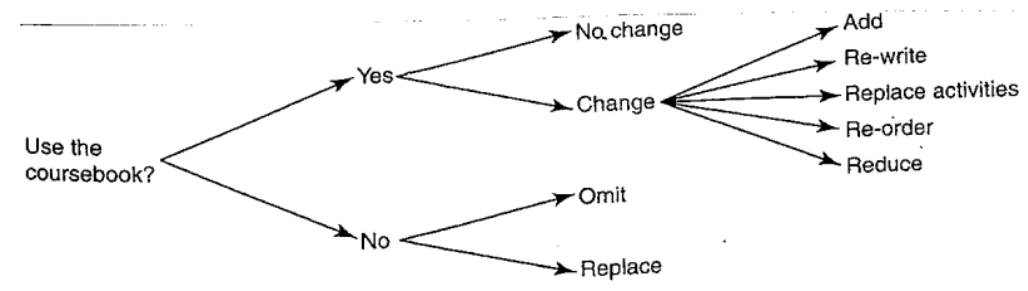

Figure 1. Options for corsebook use

\section{Background}

It is a common fact that most students from secondary schools and even from institutions of higher learning lack communication skills particularly in the English language. This is a major issue and demands top priority. The spread of globalization and ever increasing competition in job market in international level has renewed emphasis on the importance of English (Nair et al. 2012). The necessity for proficiency in English language is one of the most important prerequisite expected by the employers nowadays. A university plays an indispensable role in warranting that the undergraduates are furnished with the essential English language skills vital for the workplace (Singh, 2014). Ainol et al. (2011) found that 'Employers have lamented that poor English competency has hampered graduates' ability to communicate effectively at the workplace'. According to Isarji Sarudin et al. (2013), “... there is a global concern regarding the widening gap between the communication skills in English of job applicants and the English language competency required for employment".

Relevant studies have been done in this area show that there is glaring debility prevailing in this area. ; in an suitability in the job sector study Nair et al. (2012) concluded that the speaking, writing, social skills and overall English proficiency of new graduates were inadequate; Islam et al. (2013) and Abdul Hamid et al. (2014) in a follow up study reported that there was the widest gap found in communication skills, specifically the skill of English language usage. These researchers have recommended and mentioned various measures to be undertaken by the policy-makers, institutes, teacher, and learners to minimize this crucial issue. Possible course of actions suggested by the these researchers include: improvement efforts and corrective actions in soft-skills development, to improve and implement revised and more effective syllabus design, the need for a valid, reliable, world standard and industry-driven English competency certification test for ESL speakers etc.. To bridge the gap between graduate unemployment and the insufficient levels of English proficiency achieved by graduate student, according to Don (2015), it has already been decided that Malaysia will be using the CEFR (Common European Framework of Reference) in the further development of the national English language programme.

It is for this very reason that the Ministry of Higher Education, Malaysia embarks on a project to mitigate this problem. The Department of Higher Education, Ministry of Higher Education Malaysia initiated a project known as English Language Enhancement Project (ELEP) early 2010 with the primary aim of bringing together expertise in language teaching from the various institutions of higher education in the country to deliberate and strategize effective ways of teaching and learning active communication skills. The outcome of the project was Effective Communication Skills $(E C S)$ textbook. ECS is the result of a collaborative effort among English language expertise in a number of institutions of higher education. ECS has been written based on ELT experts' passion for teaching the skills and nurturing students with the ability to communicate effectively in any given situation.

The overall aim of the textbook is clearly stated in the Preface of the Effective Communication Skills (2011), "Effective Communication Skills is targeted for students who need to improve their basic communication skills focusing on communicative fluency. The objectives are to prepare these students for further academic undertakings or for the world of work, should they decide to start a career. The book is designed to promote wider application of accurate and appropriate English language use among post-secondary school students as well as to provide as many opportunities for them to communicate in both formal and informal contexts."

The textbook was produced with a view to help students lay a solid foundation in English in the first years of their study in the universities. Effective Communication Skills is designed to promote wider application of accurate and appropriate English language use among post-secondary school students as well as to provide as many opportunities for them to communicate in both formal and informal contexts. The objectives are to prepare these students for further academic undertakings or for the world of work, should they decide to start a career.

Under the above circumstances, this particular textbook was introduced at the Universiti Malaysia Sabah, Labuan International Campus during the academic session 2011-2012 and test-use it for $1^{\text {st }}$ year business and science undergraduate students. This survey study investigated the students' attitude toward this textbook to see whether they have positive or negative outlook towards $E C S$. 


\subsection{Study Objectives}

This paper will provide a detailed evaluation of a particular coursebook that has been introduced as a pilot project commenced by the Ministry of Higher Education, Malaysia. This study was based on the following research questions:

i) How suitable is Effective Communication Skills from the students' perspectives?

ii) What are the strengths and weaknesses of the Effective Communication Skills?

\subsection{Literature Review}

Tomlinson (2005) defines materials evaluation as a procedure that involves measuring the value or the potential value of a set of learning materials. It involves making judgments about the effects of the materials on the people using them. Evaluation of materials is always different since 'the needs, objectives, backgrounds and preferred styles of the participants will differ from context to context'. In this connection, Chambers (1997) comments that materials evaluation is a complex process. Sheldon (1987) also remarks that apart from frameworks and questionnaires, 'evaluative techniques cannot provide a foolproof formula by which all materials can be unerringly judged'. Due to this intricacy and diversity, various researchers in this field have come up with many approach and methods and have suggested different checklists for evaluating ELT materials: Williams (1983), Cunningsworth (1984), Sheldon (1987), Grant (1987), Hutchinson and Waters (1987), Breen and Candlin (1987), Dougill (1987), McDonough and Shaw (1993), Brown (1995), Ur (1996), Ellis (1997), Littlejohn (1998), Roberts (1996), Tomlinson (2005), Rubdy (2005), Jayakaran and Nimehchisalem (2011).

Williams (1983) suggested a checklist putting much emphasis on 'general, linguistic/pedagogical, and technical criteria' that consists of general features such as language items and skills; speech; grammar; vocabulary; reading; writing; technical features such as pictures, diagrams, tables etc.

Hutchinson and Waters (1987) suggested the following checklist for coursebook evaluation: audience; aims; content; methodology; other criteria etc.

Breen and Candlin (1987) recommended an interactive, two-phase guide to help teachers in choosing materials. Phase one poses questions on the usefulness of materials in terms of its aims and content; learner's objectives; teacher's objectives; functions as a classroom resource etc. Phase two focuses on 'more searching analysis' of materials in terms of learner needs and interests; learner approaches to language learning; the teaching/learning process in the classroom etc.

Sheldon (1988) offered 'common core' qualitative criteria so as to make evaluation and selection of coursebook more systematic and informed. His checklists include the following criteria each one with a set of related questions: rationality; availability; user definition; layout/graphics; accessibility; linkage; selection/grading; physical characteristics; appropriacy; authenticity; sufficiency; cultural bias; education validity; stimulus/practical revision; flexibility; guidance; overall value for money etc.

McDonough and Shaw (1997) presented with a two-stage criteria of examination: external and internal evaluation. Extrnal evaluation offers a brief overview of the materials from the outside (teachers/students book cover, introduction, table of contents). Internal evaluation inspects a closer and more detailed arrangement of skills; grading and sequencing; types of reading, listening, speaking and writing activities; suitability for different learning styles; learners/teachers adoptability to the materials etc.

Cunningsworth (1995) recommended the following criteria (each having several questions) for materials evaluation: aims and approaches; design and organization; language content; skills; topic; methodology; teacher's book; practical considerations etc.

Dubin \& Olshtain (1996) recommend the following queries for a nominal set of materials evaluation: publisher and origin of the materials; compatible of the materials with the syllabus; provision of alternatives for teachers and learners; language skills covered; authentic text types; learners and teachers response to the used materials etc.

Ellis (1997) suggested two types of materials evaluation: predictive evaluation and retrospective evaluation. Predictive evaluation includes a decision making regarding what materials to use, in other words, teachers are required to perform an evaluation of the available materials in order to resolve which are best suited to their purposes. Retrospective evaluation examines materials that have already been used, in other words, once the materials have been used, a further evaluation is undertaken to know whether the materials have 'worked' for them or not.

Tomlinson (2005) advocated three types of materials evaluation: pre-use evaluation, whilst-use evaluation and post-use evaluation. Pre-use evaluation entails forecasting the potential values of the materials for their users. This type of evaluation often is impressionistic and involves a teacher having a quick impression of its prospective value. Whilst-use evaluation involves determining the value of materials whilst using them or whilst observing them being used. This type of evaluation can be more objective and reliable than the pre-use evaluation as it makes use of measurement rather than prediction. Post-use evaluation is possibly the most valuable type of the three since it can assess the actual effects of the materials on the users. It can measure both the short-term effects concerning motivation, impact, achievability, instant learning etc. as well as the long-term effects regarding durable learning and application.

Mukundan et. al (2011) proposed a tentative English language coursebook evaluation checklist where the list of criteria was divided into two general categories that include 'general attributes' and 'learning-teaching content. General attributes comprise of relation to syllabus and curriculum; methodology; suitability to learners; physical and utilitarian 
attributes; supplementary materials etc. Learning-teaching content covers general (i.e. task quality, cultural sensitivity, as well as linguistic and situational realism); listening; speaking; reading; writing; vocabulary; grammar; pronunciation; exercises etc. In another study, Nimehchisalem and Mukundan (2015) upgraded the 2011 version where the criteria under the two general categories remain the same but the questions under each criterion was revised, upgraded and improved to cater 'to the need for a reliable, valid and practical instrument to evaluate English language teaching textbooks'.

From the above relevant literature review it is quite conclusive what Sheldon (1988) summarized as that "coursebook assessment is fundamentally a subjective, rule-of-thumb activity, and that no neat formula, grid, or system will ever provide a definitive yardstick."

There are numerous ELT textbooks evolution that has been done in Malaysia and elsewhere. Following is a list of some selected evaluation done in different countries by some researchers: Mukundan and Rezvani Kalajahi (2013, evaluated the general attributes and learning-teaching content of Form 1 to Form 5 English textbooks); Rahimpour (2013, Top Notch); Nasiri and Ahmadi (2011, retrospective analysis of Summit 2B); Hashemi and Borhani (2015, American English File series in Iranian EFL context); Sarem et al (2013, evaluated an ESP English for International Tourism textbook); Ebadi and Naderifarjad (2015, comparative study between SAMT English for Medical Students and Oxford English for Career); Rahman (2012, Interactions1 Writing); Bahar and Zaman (2013, pre-use micro evaluation of Headway Pre-Intermediate); Shah et al. (2014, English for academic Purposes); Brunton (2009, Highly Recommended: English for the hotel and catering industry); Jones (2009, Fifty-Fifty Book One); Litz (2005, English Firsthand 2); Hemsley (1997, evaluation of teachers' guides).

No evaluation has been done to this particular Effective Communicative Skills coursebook as yet. Harwood (2010) also suggests that Roberts (1996) and Ellis (1997) put emphasis on retrospective, empirical as well as predictive evaluation to make it more objective and solid. A retrospective evaluation method was adapted to this current survey study in order to check the various characteristics of ECS.

\section{Methodology}

A retrospective evaluation provides information for developing to determine if it is worthy using the materials again, which activities work and which do not, and how to modify the materials to make them more effective for further use. A retrospective evaluation also works as a means of testing the validity of a predictive evaluation and may help in ways the predictive instruments can be improved for future use. Teachers can make a retrospective evaluation impressionistically or conduct an empirical evaluation which involves a micro-evaluation where teachers select one particular interesting teaching task and gives it a detailed empirical evaluation. A series of micro-evaluation can provide the basis for a later macro-evaluation that establishes if an overall assessment of an entire set of materials has worked (Ellis, 1997). According to Mukundan (2007), a retrospective evaluation of textbooks is done because the selected book can be evaluated throughout the period it is used and re-evaluated to determine its suitability so that the results of the while-use evaluation can force it out of the classroom if it is found unsuitable. Moreover teachers are able to use the results of while-use evaluation to make the book more productive and teaching more effective by recognizing portions of the textbook needs adaptation.

As Tsiplakides (2011) observes, in a retrospective evaluation the teacher does not evaluate to determine whether a given coursebook is suitable for his/her teaching situation; rather the teacher examines materials that have already been used.

The current study exactly perform the same task since the Effective Communicative Skills coursebook has been evaluated by both learners and teachers after completion of the course with the same textbook.

\subsection{Materials}

The material used for the evaluation purposes in this study is the textbook titled Effective Communication Skills. The total number of pages in ECS is altogether 228. There is an accompanying teacher's guide comprising 112 pages.

\subsection{Limitations}

This study was limited to one public university in Labuan, Malaysia only. It is assumed that students answered the questions honestly and seriously. Another limitation of this study is that the present study is a macro level evaluation which aims to assess the overall effectiveness of the particular textbook. Moreover, in this particular survey study special emphasis has been given to students' feedback rather than the Instructors.

\subsection{Participants}

A total number of 214 students (male 88 and female 126) from Universiti Malaysia Sabah, Labuan International Campus, participated in the study. They were $1^{\text {st }}$ year students aged around 18-25 years (Malay 153 and Chinese 61). The participating undergraduate learners were studying in Business and Information Technology majoring in International Finance, International Marketing, International and Offshore Banking, International Financial Economics, Islamic Finance, Multimedia Technology and E-Commerce etc. There were also two Instructors (including the author) who taught as well as evaluated the coursebook simultaneously.

\subsection{Instrument}

This study employed two questionnaires to collect data on the points of views of students and teachers about the mentioned textbook. Both the student and teacher evaluation survey questionnaires were based on Litz (2005) with some minor modification since it served the current purpose of evaluating this particular coursebook. The original 
version is "Teacher Textbook Evaluation Scale (TTES) and the scale was developed by Sung Kyun University in 2000. The purpose of this study is to evaluate English language textbook called Effective Communication Skill taught at the tertiary level mostly from the students' perspective. For this purpose, a 25 items (for students) and a 40 items (for teachers) questionnaires were set based on seven criteria. The total number of participants of the study was 217 including 3 instructors ( 1 male and 2 female) and 214 students (88 males and 126 females). This study produced qualitative and quantitative data through questionnaire. The data was analyzed mostly following a qualitative approach. Averages were calculated from a scale of $1-5$ (i.e. $1+2=$ Strongly Disagree, $3+4=$ Disagree, $5+6=$ Uncertain, $7+8=$ Agree, $9+10=$ Strongly Agree). A total of 223 (220 for students and 3 for teachers) questionnaires were distributed among the undergraduate students during the semester 1 session 2011-2012 at University Malaysia Sabah, Labuan International Campus, Malaysia. A number of 6 questionnaires were rejected due to incomplete and incorrect responses.

The questionnaire was composed of two sections. The first section requested background information such as age, gender, nationality, educational background. The second section of the questionnaire consisted of 25 items related to practical considerations, layout and design, activities, skills, language types, subject and content, and overall consensus in the textbook were selected (40 items for instructors under the same seven criteria).

\subsection{Data Analysis}

This study produced qualitative data through questionnaires. Averages were calculated from a scale of 1-5 (out of a 110 scale from Litz 2005 questionnaires) in the questionnaires (for students and teachers) for each item to describe the overall picture of how the students and teachers rated the textbook in terms of seven criteria. In fact, the author tries to analyze and evaluate the current textbook based on the guidelines and framework presented in the available checklist. The researcher has obtained a full knowledge over the whole book including its content and its different exercises as a result of careful examination of the book, using the textbook as a course materials for around 50 students and through consultation with two other practicing teachers who were teaching the same textbook in semester 1 session 2011-2012 at University Malaysia Sabah, Labuan International Campus, Malaysia and who also took part in and conducted the questionnaire survey with the additional 164 students.

\section{Analysis and Discussion}

The following analysis and discussion was based on data collected and interpreted from the two questionnaires and also from the classroom observation and additional feedback from the students attending the course.

\subsection{The Textbook- Value, Content, and Methodology}

The material used for the evaluation purposes in this study is the textbook titled Effective Communication Skills. ECS is altogether 228 pages and the textbook comes with a teacher's guide comprising 112 pages.

Table 1. Students' textbook evaluation average on price and accessibility

\begin{tabular}{llllll}
\hline & Strongly Disagree & Disagree & Uncertain & Agree & Strongly Agree \\
& 1 & 2 & 3 & 4 & 5 \\
\hline 1The price of the textbook is reasonable & 21 & 22 & 75 & 47 & 49 \\
& $9.8 \%$ & $10.3 \%$ & $35 \%$ & $21.9 \%$ & $22.9 \%$ \\
\hline 2 The textbook is easily accessible & 13 & 14 & 60 & 79 & 48 \\
& $6.1 \%$ & $6.5 \%$ & $28 \%$ & $36.9 \%$ & $22.4 \%$ \\
\hline
\end{tabular}

The cost is one important factor in relation to choosing a textbook. While the cost might be not a necessary important factor as most ESL/EFL textbooks are published in the western countries like UK and USA; the same textbooks are used in many less-developed nations where price usually play an important role in textbook selection. This is particularly an issue in countries like Malaysia where many students with limited incomes are required to purchase the books for a mandatory second/foreign language course. From the students' evaluation (only $44.8 \%$ agreeing, whereas $20.1 \%$ disagreeing and 35\% are not sure), it is clear that the price of ECS is not cheap or reasonable; the teachers' evaluate show that $E C S$ is not costly and the price is sensible.

Another factor for textbook evaluation is accessibility or availability. A purchasable textbook has to be currently in print and readily obtainable. From both the students' (59.3\% agreeing, 28\% uncertain, while $12.6 \%$ disagreeing) and teachers' evaluation, it is clear that ECS is readily accessible. Actually, this particular textbook was published by Ministry of Higher Education, Malaysia in 2011 and was available for institutes only so that students have direct access to the coursebook immediately after the course was offered at the University.

Another important factor to be taken into consideration here is the author's approach to teaching methodology. In ECS from the Preface to the cover, nowhere it is mentioned what particular teaching methodology was applied for this textbook. ECS features ten learning units and each unit is divided into three sections: retrieving information, processing information and communicating information. The sections are believed to develop the students' critical thinking skills as they go through the activities in the units. Each unit provides meaningful language practices with the integration of the four (albeit three since there is no listening component in the coursebook) language skills and through appropriate contexts. Although the activities provide more opportunity for spoken communication, the units also include activities for written communication including supplementary grammar and vocabulary building. 
The communicative approach is based on the idea that the purpose and goal of language learning and teaching is communication. In a communicative language teaching scenario, language teachers are encouraged to use authentic materials for increasing students" motivation through inclusion of "real" examples of language practice and to demonstrate how language is used by a community of L1speakers to aid specific goals (McKay, 2013). According to Yalden (1983, cited in Celce-Murcia, 2001), in a communicative or task-based syllabus real-world tasks and authentic materials are used to design language courses. Nunan (2004) states that “... pedagogical tasks involve communicative language use in which the user's attention is focused on meaning rather than grammatical form. ... deployment of grammatical knowledge to express meaning, high-lighting the fact that meaning and form are highly interrelated, and that grammar exists to enable the language user to express different communicative meanings". Task-based language teaching can enable comprehension of input, it can assist communication and attention to output, and the expansion of progressively target-like speech production.

Even though the teaching methodology or teaching approach of the textbook is vague, yet all activities and exercises in $E C S$ is placed on natural and authentic communication, both receptively and productively with the goal of establishing communicative competence and as such can be termed as useful and effective for the learners and teachers. Therefore, the underlying approach followed in this textbook is very much similar to an extended version of communicative language teaching method. ECS clearly advocates and implements a PPP sequence, i.e. presentation, practice, and production so that "learners can be guided from controlled practice of language features to free and automatic production of language in any or all of the four skills" (Hinkel, 2010).

\subsection{Layout and Design}

With regards to the overall look of a textbook, Howard and Major (2005) have emphasized the physical appurtenance, user-friendliness, durability, and ability to reproduce for class use as some of the most sought-after elements in a textbook. Ellis and Ellis (1987) also advocated for relevance, accessibility and cohesion in terms of design in an EFL coursebook. In other words, the layout and design of a textbook refers to its organization and presentation of language items and activities and both the students' and teachers' evaluation demonstrate positively to these particular aspects of this book. This textbook is divided into ten units, and each unit is divided into three lessons. Unit goals and clear learning objectives are given at the contents page. The course components are effectively and clearly organized around specific topics such as now and then, things people do, times to rejoice, socilising in cyberspace, influence of media, bringing about change, the environment and us, say yes to good attitude, cultural practices, expectations, etc. The overall layout and design of each individual unit and its contents are organized as follows:

- A brief introduction which contains topic preview that introduces the unit topic and prepares learners for the three lessons in the unit;

- Each of the three lessons begins with a reading text based on the same background that is designed to cover a range of skills such as retrieving information, processing information, communicating information, followed by vocabulary building and reading comprehension questions with additional reading texts and similar exercises.

- Individual, pair and group work, role-playing activities are encouraged in each unit through some contextual theme with specific notions and functions;

- Each unit concludes with a writing/presentation prompts.

Table 2. Students' textbook evaluation average on layout and design

\begin{tabular}{llllll}
\hline & Strongly Disagree & Disagree & Uncertain & Agree & Strongly Agree \\
& 1 & 2 & 3 & 4 & 5 \\
\hline 3 The layout and design is appropriate and & 2 & 14 & 56 & 82 & 60 \\
clear & $0.9 \%$ & $6.5 \%$ & $26.2 \%$ & $38.3 \%$ & $28 \%$ \\
\hline 4 The textbook is organized effectively & 2 & 14 & 53 & 84 & 61 \\
& $0.9 \%$ & $6.5 \%$ & $24.8 \%$ & $39.3 \%$ & $28.5 \%$ \\
\hline
\end{tabular}

This criterion was measured through two items in the questionnaires. From the students' evaluation, it is found that items 3 (66.3\% agreeing), 4 (67.8\% agreeing) are evaluated affirmatively; the teachers evaluated item them in the same manner. Although the course components are effectively and clearly organized around specific topics, these topics are mundane and may be too academic to the students. It can be possible to say that the units do not cover variety of topics to cater to the interest of the present-day younger learners. Another drawback of overall layout and design is that there is a glaring lack of vocabulary lists with their meaning, expression glossaries, grammar references, communicative expansion etc. There is also this glaring limitation of this textbook in term of its design and organization is that each unit is almost identical to the next and that makes it not so interesting and motivating to the learners.

\subsection{Activities}

According to Brown (2001), activities may refer to almost anything that learners do in the classroom. They include roleplay, drills, games, peer-editing, small-group information-gap exercises, and so forth. According to the Encyclopedic Dictionary of Applied Linguistics (1999), there has been a consistent move towards motivation-enhancing learning activities with relation to classroom language teaching and learning. With five types of reward built into materials that 
would encourage students to persevere and succeed in the language classroom such as: relevant content to students' own language needs; inclusion of all the language necessary for the stated aim of the course; linguistic and cultural authenticity; students' satisfaction with each lesson with a sense of benefit rather than simple progression; students' immediate use of the materials etc.

Table 3. Students' textbook evaluation average on activities

\begin{tabular}{|c|c|c|c|c|c|}
\hline & $\begin{array}{l}\text { Strongly Disagree } \\
1\end{array}$ & $\begin{array}{l}\text { Disagree } \\
2\end{array}$ & $\begin{array}{l}\text { Uncertain } \\
3\end{array}$ & $\begin{array}{l}\text { Agree } \\
4\end{array}$ & $\begin{array}{l}\text { Strongly Agree } \\
5\end{array}$ \\
\hline \multirow{2}{*}{$\begin{array}{l}5 \text { The textbook provides a balance of } \\
\text { activities }\end{array}$} & 3 & 14 & 69 & 76 & 52 \\
\hline & $1.4 \%$ & $6.5 \%$ & $32.2 \%$ & $35.5 \%$ & $24.3 \%$ \\
\hline \multirow{2}{*}{$\begin{array}{l}6 \text { The activities encourage sufficient } \\
\text { communicative and meaningful practice. }\end{array}$} & 4 & 8 & 65 & 86 & 51 \\
\hline & $1.9 \%$ & $3.7 \%$ & $30.4 \%$ & $40.2 \%$ & $23.8 \%$ \\
\hline \multirow{2}{*}{$\begin{array}{l}7 \text { The activities incorporate individual, pair } \\
\text { and group work }\end{array}$} & 6 & 15 & 57 & 82 & 54 \\
\hline & $2.8 \%$ & $7 \%$ & $26.6 \%$ & $38.3 \%$ & $25.2 \%$ \\
\hline \multirow{2}{*}{$\begin{array}{l}8 \text { The grammar point and vocabulary items } \\
\text { are introduced in motivating and realistic } \\
\text { contexts }\end{array}$} & 4 & 14 & 50 & 78 & 68 \\
\hline & $1.9 \%$ & $6.5 \%$ & $23.4 \%$ & $36.4 \%$ & $31.8 \%$ \\
\hline \multirow{2}{*}{$\begin{array}{l}9 \text { The activities promote creative, original } \\
\text { and independent responses }\end{array}$} & 4 & 7 & 63 & 81 & 59 \\
\hline & $1.9 \%$ & $3.3 \%$ & $29.4 \%$ & $37.9 \%$ & $27.6 \%$ \\
\hline \multirow[t]{2}{*}{10 The number of exercises is suitable } & 0 & 15 & 57 & 77 & 65 \\
\hline & $0 \%$ & $7 \%$ & $26.6 \%$ & $35.9 \%$ & $30.4 \%$ \\
\hline
\end{tabular}

This criterion was measured through six items in the questionnaires. From the students' evaluation, it is found that items 5 (59.8\% agreeing), 6 (64\% agreeing), 7 (63.5\% agreeing), 9 (68.2\% agreeing), and 10 (66.3\% agreeing) affirmatively; the teachers' evaluation of items $5,7,8,9,19$ are done positively and item 6 slightly less positively. Both students and teachers think that the textbook provide a balance of activities, incorporate pair and group work. According to a large number of students, grammar activities, vocabulary items and exercises are inadequate and unsuitable. There are not sufficient numbers of exercises for practicing vocabulary items attempting to develop the skill, for example, to guess the meaning of unknown words, or to find synonyms or antonyms. ECS contains some role-play and information-gap which serves as fluency practice as well as some open-ended discussion questions that allow students to personalize their responses, share information, and express their thoughts and experiences in English. There are also some noncommunicative exercises that require controlled responses, such as drilling, listing, comparing, matching and filling-inthe-blanks.

\subsection{Skills}

Hinkel (2006: 113) opines that "in an age of globalization, pragmatic objectives of language learning place an increased value on integrated and dynamic multi-skill instructional models with a focus on meaningful communication and the development of learners' communicative competence." In English language teaching the four skills of listening, speaking, reading and writing has got paramount importance. The integration of four skills is the only plausible approach within a communicative and interactive framework (Brown, 2001). McDonough and Shaw (1997), Oxford (2001), Brown (2001), Hinkel (2010), Howard and Major (2005) have all advocated for an integration of multi-skilled based course contents in any ESL/EFL textbooks.

Table 4. Students' textbook evaluation average on skills

\begin{tabular}{|c|c|c|c|c|c|}
\hline & $\begin{array}{l}\text { Strongly Disagree } \\
1\end{array}$ & $\begin{array}{l}\text { Disagree } \\
2\end{array}$ & $\begin{array}{l}\text { Uncertain } \\
3\end{array}$ & $\begin{array}{l}\text { Agree } \\
4\end{array}$ & $\begin{array}{l}\text { Strongly Agree } \\
5\end{array}$ \\
\hline 11 The materials include and focus on the & 4 & 10 & 64 & 84 & 52 \\
\hline skills that I need to practice & $1.9 \%$ & $4.7 \%$ & $29.9 \%$ & $39.3 \%$ & $24.3 \%$ \\
\hline 12 The materials provide an appropriate & 3 & 11 & 76 & 69 & 55 \\
\hline balance of the four language skills. & $1.4 \%$ & $5.1 \%$ & $35.5 \%$ & $32.2 \%$ & $25.7 \%$ \\
\hline 13 The textbook pays attention to sub-skills & 0 & 11 & 75 & 75 & 53 \\
\hline $\begin{array}{l}\text { - i.e. listening for gist, note-taking, } \\
\text { skimming for information, etc. }\end{array}$ & $0 \%$ & $5.1 \%$ & $35 \%$ & $35 \%$ & $24.8 \%$ \\
\hline
\end{tabular}

This criterion was measured through three items in the questionnaires. From the students' evaluation, it is found that items 11 (63.6\% agreeing), 12 (57.9\% agreeing), and 13 (59.8\% agreeing) are evaluated positively; the teachers also evaluated all the three items favourably.

ECS has a communicative fluency syllabus that covers both productive i.e. speaking and writing and receptive i.e. reading as the predominating skills without any listening activities. Actually, the main focus of ECS is reading and writing. There are much more reading comprehension passages than dialogues and prompts for speaking. In reading activities, sub-skills such as making predictions, extracting specific information (scanning), acquiring general information (skimming), extracting detailed information, and for inferring meaning from context can be seen in the 
textbook. Apart from listening skills, there are no specific lessons on speaking skill, i.e. dialogue, functional and conversational expressions, pronunciation, word and sentence stress, and intonation etc. Focus on conversation fluency activities are contained through reading components. Speaking practice takes place through oral presentation, some role plays, pair and group work, and class activities. Writing activities in ECS ask students to perform tasks of various kinds such as paragraph, essay, letter and CV writing, etc. The positive point is that the textbook leads students from simple controlled writing activities to guided writing activities, and gradually expose them to free activities.

4.5 Language Type

Cathcart (1989) and Lee (1995) (as cited in Litz, 2005: 30-31) remark that when students are exposed to authentic materials certainly these models of language are not only genuine but also represent real-life language in terms of discourse structure. Moreover, the use of these materials brings greater realism and relevance to the ESL/EFL classroom and they can enhance learner motivation.

Table 5. Students' textbook evaluation average on language type

\begin{tabular}{llllll}
\hline & Strongly Disagree & Disagree & Uncertain & Agree & $\begin{array}{l}\text { Strongly Agree } \\
5\end{array}$ \\
\hline 14 The language used in the textbook is & 1 & 3 & 2 & 3 & 4 \\
authentic - i.e. like real-life English. & $1.4 \%$ & 15 & 53 & 94 & 49 \\
\hline 15 The language used is at the right level & 5 & $7 \%$ & $24.8 \%$ & $43.9 \%$ & $22.9 \%$ \\
for my current English ability & $1.9 \%$ & 15 & 64 & 68 & 62 \\
\hline 16 The progression of grammar points and & 0 & $7 \%$ & $29.9 \%$ & $31.8 \%$ & $28.9 \%$ \\
vocabulary items is appropriate & $0 \%$ & 15 & 54 & 83 & 62 \\
\hline 17 The grammar points were presented with & 0 & $7 \%$ & $25.2 \%$ & $38.8 \%$ & $28.9 \%$ \\
brief and easy examples and explanations & $0 \%$ & 13 & 65 & 81 & 55 \\
\hline 18 The language functions exemplify & 0 & $6 \%$ & $30.4 \%$ & $37.9 \%$ & $25.7 \%$ \\
$\begin{array}{l}\text { English that I will be likely to use in the } \\
\text { future }\end{array}$ & $0 \%$ & 13 & 49 & 83 & 69 \\
\hline
\end{tabular}

This criterion was measured through five items in the questionnaires. From the students' evaluation, it is found that items 14 (66.8\% agreeing), 15 (60.7\% agreeing), 16 (67.7\% agreeing), 17 (63.6\% agreeing), and 18 (71\% agreeing), are evaluated in a very positive manner; whereas the teachers evaluated items $14,16,17$, and 18 quite positively and item 15 slightly less positively. From the students' responses, it is found that the language used in the textbook is authentic. Students stated that the progression of grammar points and vocabulary items are not appropriate. Another reason for students' disappointment is that ECS does not give detailed explanation about grammatical structures and usages. Grammar points are introduced in the context of reading passages and without enough repetition and exercises. However, questions on correct level of language use and brief and easy explanations of grammar points have got students' highest approval.

\subsection{Subject and Content}

According to Litz (2005), many theorists indisputably believe that language is culturally bound and since language teaching and culture can not be specifically detached from each other it is possibly unavoidable that students will be exposed to some elements of the target language culture when using many ELT textbooks. ELT textbooks should present an accurate representation of the target language culture.

Table 6. Students' textbook evaluation average on subject and content

\begin{tabular}{|c|c|c|c|c|c|}
\hline & $\begin{array}{l}\text { Strongly Disagree } \\
1\end{array}$ & $\begin{array}{l}\text { Disagree } \\
2\end{array}$ & $\begin{array}{l}\text { Uncertain } \\
3\end{array}$ & $\begin{array}{l}\text { Agree } \\
4\end{array}$ & $\begin{array}{l}\text { Strongly Agree } \\
5\end{array}$ \\
\hline 19 The subject and content of the textbook & 2 & 15 & 51 & 81 & 65 \\
\hline $\begin{array}{l}\text { is relevant to my needs as an English } \\
\text { language learner }\end{array}$ & $0.9 \%$ & $7 \%$ & $23.8 \%$ & $37.9 \%$ & $30.4 \%$ \\
\hline 20 The subject and content of the textbook & 2 & 11 & 59 & 79 & 63 \\
\hline is generally realistic & $0.9 \%$ & $5.1 \%$ & $27.6 \%$ & $36.9 \%$ & $29.4 \%$ \\
\hline 21 The subject and content of the materials & 0 & 15 & 55 & 73 & 71 \\
\hline is interesting, challenging and motivating & $0 \%$ & $7 \%$ & $25.7 \%$ & $34.1 \%$ & $33.2 \%$ \\
\hline 22 There is sufficient variety in the subject & 0 & 11 & 58 & 84 & 61 \\
\hline and content of the textbook & $0 \%$ & $5.1 \%$ & $27.6 \%$ & $39.3 \%$ & $28.5 \%$ \\
\hline 23 The materials are not culturally biased & 0 & 10 & 70 & 66 & 68 \\
\hline and they do not portray any negative & $0 \%$ & $4.7 \%$ & $32.7 \%$ & $30.8 \%$ & $31.8 \%$ \\
\hline
\end{tabular}

This criterion was measured through five items in the questionnaires. From the students' evaluation, it is found that items 19 (68.3\% agreeing), 20 (66.3\% agreeing), 21 (67.3\% agreeing), 22 (67.8\% agreeing), 23 (62.6\% agreeing) are evaluated favourably; the teachers also the same five items quite in a positive manner. It is gathered from the students' feedback that the subject and content of ECS could have been more relevant, interesting, challenging and motivating for them. 
Table 7. Students' textbook evaluation average on overall consensus

\begin{tabular}{llllll}
\hline & Strongly Disagree & Disagree & Uncertain & Agree & Strongly Agree \\
& 1 & 2 & 3 & 4 & 5 \\
\hline 24 The textbook raises my interest in further & 4 & 18 & 50 & 73 & 69 \\
English language study & $1.9 \%$ & $8.4 \%$ & $23.4 \%$ & $34.1 \%$ & $32.2 \%$ \\
& & & & & \\
& 11 & 19 & 51 & 63 & 70 \\
25 I would choose to study this textbook & $5.1 \%$ & $8.9 \%$ & $23.8 \%$ & $29.4 \%$ & $32.7 \%$ \\
\hline again & & &
\end{tabular}

This criterion was measured through two items in the questionnaires. From the students' evaluation, it is found that items 24 (68.3\% agreeing), 25 (62.1\% agreeing) are evaluated favourably as is the case of the teachers evaluation also produced the same positive response. Students' response to the questions on the textbook's ability to raise interest in further English language study and choosing it again as a study material have got some very encouraging feedback. Instructors have recommended this coursebook for raising student's interest level, and they have also recommended $E C S$ as a repeat study material for the students in the future.

\subsection{Teacher's Guide}

According to Hemsley (1997), "the teachers' guide states the purpose of the associated teaching materials and describes the rationale behind them. The TG will encourage the development of teaching skills and assist the teacher to understand the course as a whole. It will provide guidance on how to use the material and the linguistic and cultural information required for its effective use. ... a good TG will also help teachers develop towards an eventual position of self-reliance and independence of such explicit guidance". Hemsley justifies the evaluation of TG by claiming that frequently the teacher's guide do not fulfills the teacher's needs, the guides are not guiding them even though they should do so. He further prescribes two types of evaluation: universal and detailed evaluation.

The ECS teacher's guide has got two sections where the first part is devoted to some elaborate lesson plans for activities and exercises in each unit and the second part has got suggested answer keys that are quite useful and handy for the teachers. Here the instructors have given quite some positive and favourable feedback regarding the teacher's manual. Since the current survey study of the textbook emphasized more on the students' response, the additional fifteen items in the teacher's questionnaire are not taken into account in this analysis. It is worth mentioning here that the additional fifteen items in terms of seven criteria in the teacher's questionnaire have got some favourable response from the instructors.

\subsection{Overall Analysis - Students/Teachers}

The following figures provide an overall impression of the average analysis of both the students' and teachers' evaluation of the Effective Communication Skills coursebook.

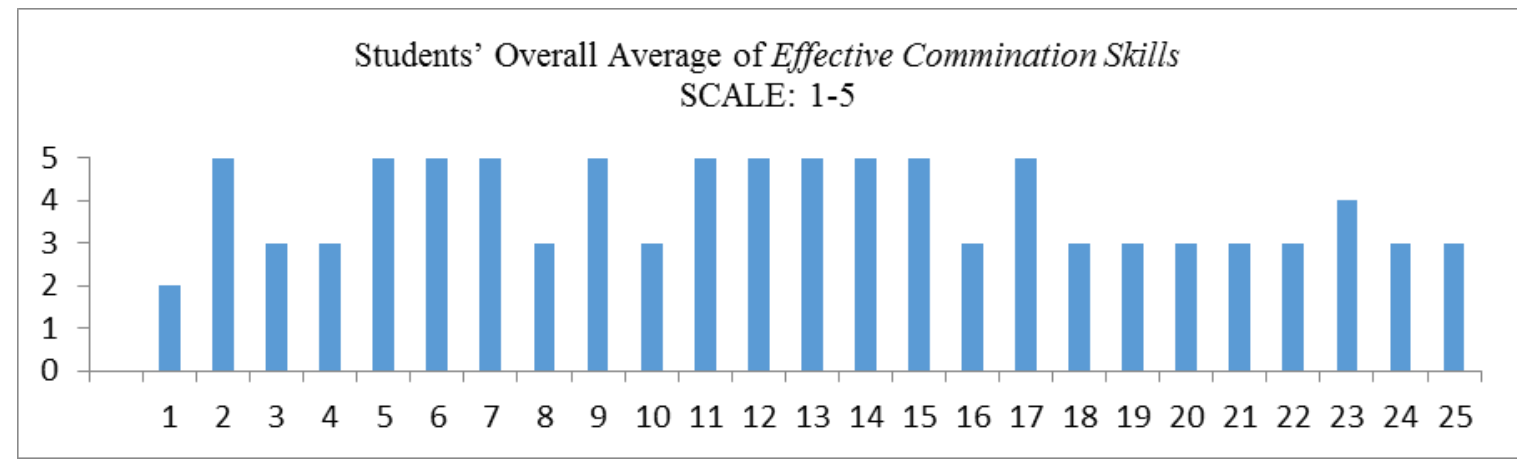

Figure 2. Students' Overall Average

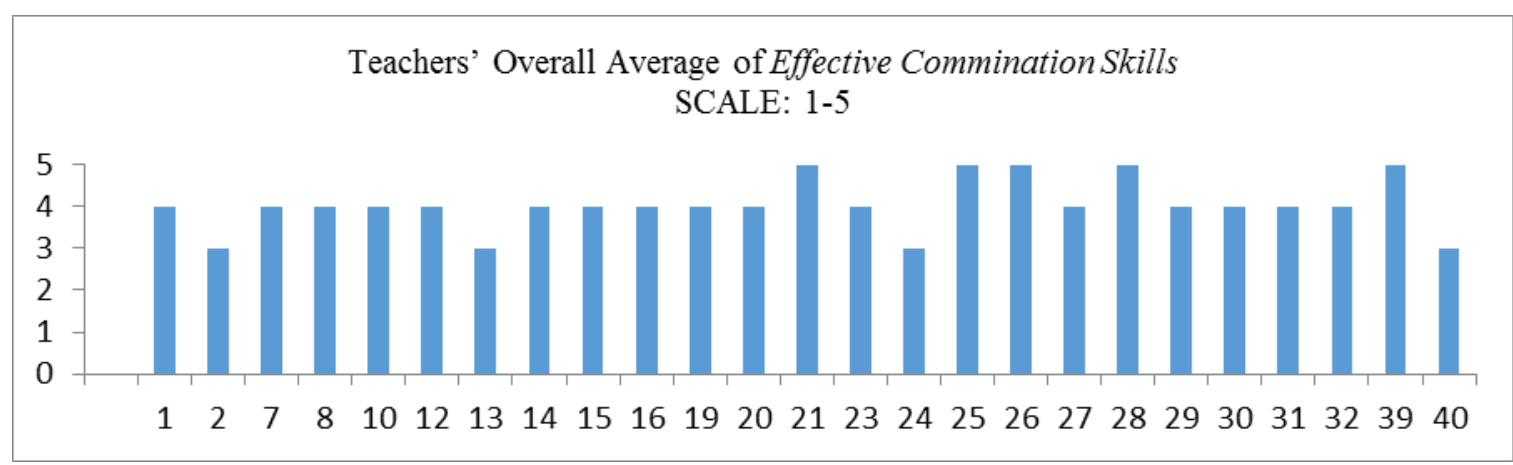

Figure 3. Teachers' Overall Average 


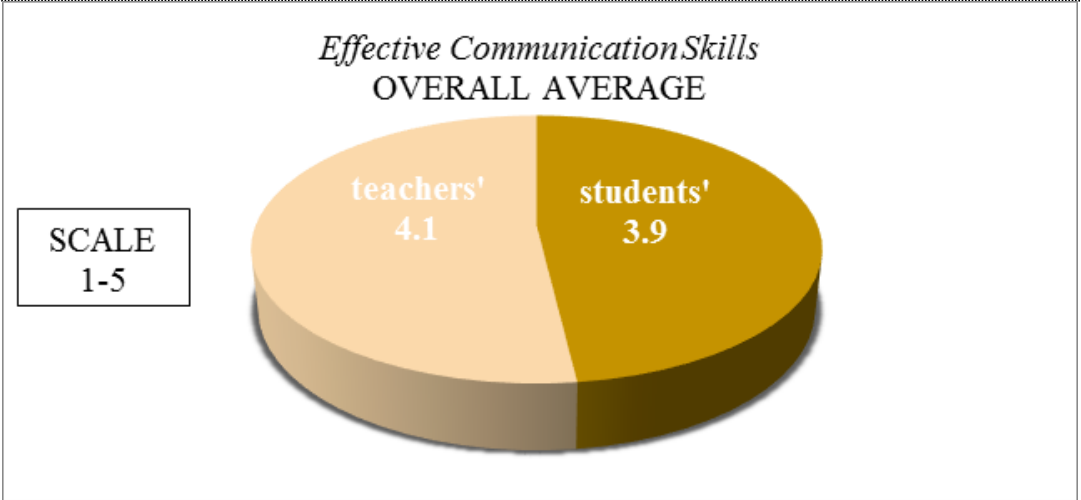

Figure 4. Students'/Teachers' Overall Average

Figure 2 shows an overall average of students' evaluation based on the 25 items against seven criteria in the questionnaire, while figure 3 exhibits an overall average of teachers' evaluation of the coursebook based on the same number of items under seven criteria. As is shown in figure 3, the serial number of items in the teachers' questionnaire is slightly different than the students'; nonetheless both the questionnaires have got the same items against seven criteria to best evaluate ECS. From figure 4, we may surmise that the overall average of students' evaluation (3.9 out of a 1-5 scale) is marginally lower than the teachers' evaluation (4.1 out of a 1-5 scale) of the ECS coursebook. Finally, it can be presumed that both the students' and the teachers' evaluation of the Effective Communication Skills course is quite favorable and positive.

\section{Strengths and Weaknesses of $E C S$}

Following is a summary of some of the weaknesses and strengths of the ECS from the perspectives of students' and instructors survey and after an overall macro analysis of the whole textbook.

The ECS seems to have the following shortcomings found in the coursebook:

- The font type, font size, and the use of colour, pictures and clip arts in the textbook seem to be not so appropriate, interesting and motivating for the students.

- Majority of the tasks require learners to respond whereas there are a small proportion of tasks that require students to initiate the language use. This is not very conducive for an active learner-centred class.

- ECS completely lacks the receptive skill like listening components in the textbook. The units in the textbook do not include sufficient number of activities that allow the learners to learn through listening. This is a serious drawback for a textbook primarily intended to enhance students' communicative fluency.

- There is no review or consolidation chapter/unit in the textbook.

- The textbook do not include adequate number of exercises to revise new words.

- The presentation of grammar points is not adequate.

- There are not additional supplementary materials with the textbook except the Teacher's Manual.

There are also a number of commending features of ECS as a coursebook:

- This textbook is a collaborative and passionate effort by the local ELT experts and instructors.

- The textbook is durable in terms of use.

- Titles of the reading passages are interesting, and the activities and exercises encourage individual, pair and group work.

- There is logical sequencing of the content and the instructions are clear for the students.

- Reading passages and examples in the textbook are related to their daily lives. And the topics are up-to-date.

- Although most of the exercises focus on language practice, there are some activities that focus on language use, e.g. role-play and interactive exercises. This will encourage students to use the language for communication in the real world.

\section{Conclusion and Recommendations}

ECS has the potential to be a useful course material for tertiary-level students in Malaysia if the following necessary revisions can be done for further improvement and embellishment:

- Inclusion of listening components will enhance the integration of four skills.

- Inclusion of additional spoken English components such as dialogues, language notes on notions/functions etc.

- Inclusion of contextual grammar points and exercises.

- Inclusion of review units.

- Provide additional supplementary materials such as students' work book, CD etc.

- Correction of spelling etc. in both the students' and teacher's guide.

A textbook is not an absolute solution to the learners' needs and thus cannot be final answer to this issue. We should rather take whatever is beneficial to the teaching and learning and adapt, complement or modify what is not satisfactory. 
This can ensure that the textbook will achieve its projected purposes. It is observed from the analysis and discussion that ECS has got some shortcomings that require further improvements and reconsiderations. On the other hand, this textbook has the potential for the under-graduate learners as a useful language learning material with some modification and revision.

The prime objectives of the Effective Communication Skills were to promote wider application of accurate and appropriate English usage among undergraduates so as to develop communicative fluency through meaningful language practices and integration of the four language skills. This particular coursebook was developed not fully with commercial purposes in mind; but was rather driven by considerations of the requirements and prerequisites of the target leaners and principles of language acquisition. Tomlinson (2011) cites an example of a textbook development project team led by 17 teachers at Sultan Qaboos University in Muscat, Oman where the main focus was centred on 'what facilitates language acquisition (i.e. universal criteria) and what is needed and wanted by their target learners (i.e. local criteria)'. Tomlinson (2013) further proposes an idea of humanizing the ELT coursebook by reducing the nonhumanistic elements of the book, by expanding and adding to those sections which invite the learners to think, feel and do in order to learn. Through a choice of route, a choice of texts and a choice of tasks can easily personalize coursebooks and thus make them more humanistic. He contends that one of the main reasons why global coursebooks are not normally humanistic is that in trying to cater for everybody they end up engaging nobody. "One way of connecting the coursebook to the real world which the learner lives in is obviously to localize coursebooks".

$E C S$ is the end-product of the same ideas to bring out the best in the undergraduates communicative fluency. Since the primary object of this particular textbook was to test-use it as supplementary materials to help enhance under-graduate students' communicative fluency in the public universities in Malaysia, it is sincerely expected and hoped that the Ministry of Higher Education will eventually come up with an updated and revised textbook to cater to its objectives and purposes.

\section{Acknowledgement}

The author expresses his sincerest gratitude to Pn. Siti Khatijah Johari, Sr. Lecturer and Pn. Naheeda Ahasan, Teacher, UMSKAL for their kind assistance and cooperation in conducting the questionnaires survey and for providing valuable feedback, comments regarding the ECS. This research paper was presented at the $17^{\text {th }}$ ESEA Conference, University Malaya, Malaysia in 2013.

\section{References}

Abdul Hamid, M.S., Islam, R., \& Abd Manaf, N.H. (2014). Malaysian graduates' employability skills enhancement: an application of the importance performance analysis. Journal for Global Business Advancement, 7(3), 181-197.

Ainol Madziah, Z., Isarji, S., Nordin, M.S., \& Tunku Ahmad, T.B. (2011). English Competency for Entry-Level Employment: A Market Research on Industrial Needs. PEC White Paper_Vs3. Accessed at: https://www.prestariang.com.my/contents/resource.

Bahar, H.B. \& Zaman, B. (2013). Significance of Text Book Evaluation for the Purpose of Effective Second Language Acquisition. ISOR Journal of Humanities and Social Science, 12(5), 70-77.

Breen, M.P. \& Candlin, C.N. (1987). Which materials? a consumer's and designer's guide. In L. E. Sheldon (Ed.),

ELT textbooks and materials: problems in evaluation and development (13-28). London: Modern English Publications.

Brown, H. D. (2001). Teaching by principles: An interactive approach to language pedagogy. New York: Longman.

Brown, J. (1995). The Elements of Language Curriculum. Boston, MA: Heinle and Heinle.

Brunton, M. (2009). Evaluation of Highly Recommended: A textbook for the Hotel and Catering Industry. ESP World, 8/1(22), 1-6.

Celce-Murcia, M. (2001). Teaching methodology. In M. Celce-Murcia (Ed.), Teaching English as a Second or Foreign Language (3-11). USA: Heinle \& Heinle.

Chambers, F. (1997). Seeking Consensus in Coursebook Evaluation. ELT Journal, 51(1), 29-35.

Cunninngsworth, A. (1984). Evaluating and Selecting EFL Teaching Materials. London: Heinemann.

Cunninngsworth, A. (1995). Choosing your coursebook. Oxford: Heinemann.

Don, Zuraidah Mohd. (2015). English language proficiency, graduate employability, and the role of the CEFR. Asean Seminar on "Best Practices in English Teaching in Asean Universities", 4-10.

Dougill, J. (1987). Not so obvious. In L. E. Sheldon (Ed.), ELT textbooks and materials: problems in evaluation and

Development (29-36). London: Modern English Publications.

Dubin, F. \& Olshtain, E. (1996). Course Design. USA: Cambridge University Press.

Ebadi, S. \& Naderifarjad, Z. (2015). Evaluation of EAP Textbooks: A Comparison between SAMT English for Medical Students and Oxford English for Career. Journal of Studies applied Linguistics and Language Research, 2(3), 133-149. 
Ellis, J. \& Ellis, P. (1987). Learning by design: Some criteria in EFL coursebooks. In L. E. Sheldon (Ed.), ELT textbooks and materials: problems in evaluation and development (90-98). London: Modern English Publications.

Ellis, R. (1997). The Empirical Evaluation of Language Teaching Materials. ELT Journal. 51(1), 36-41.

Encyclopedic Dictionary of Applied Linguistics: A Handbook for Language Teaching. (1999). K. Johnson \& H. Johnson, (Eds.). Oxford: Wiley-Blackwell.

Grant, N. (1987). Making the Most of Your Textbook. New York: Longman.

Graves, K. (2003). Coursebooks. In D. Nunan (Ed.), Practical English Language Teaching (225-246). New York: McGraw Hill/Contemporary.

Hajibah, O. et. al. (2011). Effective Communication Skills. Shah Alam: Universiti Teknologi MARA Press, Malaysia.

Hajibah Osman et al. (2011). Effective Communication Skills: Guide for Teachers and Suggested Answer Key. Shah Alam: Universiti Teknologi MARA Press, Malaysia.

Harmer, J. (2007). The Practice of English Language Teaching. $4^{\text {th }}$ Edition. England: Pearson Education Limited.

Harwood, N. (2010). Issues in materials development and design. In N. Harwood (Ed.), English Language Teaching

Materials: Theory and Practice (3-30). USA: Cambridge University Press.

Hashemi, S.Z. \& Borhani, A. (2015). Textbook Evaluation: An Investigation into “American English File” Series. International Journal on Studies in English Language and Literature, 3(5), 47-55.

Hedge, T. (2003). Teaching and Learning in the Language Classroom. Oxford: Oxford University Press.

Hemsley, M. (1997). The evaluation of teachers' guides—design and application. English Language Teacher Education and Development, 3(1), 72-83.

Hinkel, E. (2006). Current Perspectives on Teaching the Four Skills. TESOL Quarterly, 40(1), 109-131.

Hinkel, E. (2010). Integrating the four skills: Current and historical perspectives. In R.B. Kaplan (Ed.), Oxford Handbook in Applied Linguistics (110-126). UK: Oxford University Press.

Howard, J. \& Major, J. (2005). Guidelines for designing effective English language teaching materials. Seoul, South Korea: Ninth Conference of the Pan-Pacific Association of Applied Linguistics, Oct 2004, 101-109.

Hutchinson, T. (1987). What's underneath? An interactive view of materials evaluation. In L. E. Sheldon (Ed.), ELT textbooks and materials: problems in evaluation and development (37-44). London: Modern English Publications.

Hutchinson, T. \& Waters, A. (1987). English for Specific Purposes: A learning-centered approach. Cambridge: Cambridge University Press.

Isarji Sarudin, Zainab, M.N., Zubairi, A.M., Tunku Ahmad, T.B., \& Nordin, M.S. (2013). Needs Assessment of Workplace English and Malaysian Graduates' English Language Competency. World Applied Sciences Journal, 21 (Special Issue of Studies in Language Teaching and Learning), 88-94.

Islam, R., Abdul Hamid., M.S., Abd Manaf., N.H. (2013). Enhancing graduates'employability skills: A Malaysian case. In Academy of International Business (MENA), Third Annual Conference 2013, 12-14 January, 2013, Cairo, Egypt.

Jones, S. (2009). A retrospective evaluation of a ELT coursebook for a Korean university conversation course. MA TESOL/TEFL, 3 .

Littlejohn, A. (2003). The analysis of language teaching materials. In B. Tomlinson (Ed.), Materials Development in Language Teaching (190-215). Cambridge: Cambridge University Press.

Litz, D.R.A. (2005). Textbook Evaluation and ELT Management: a South Korean Case Study. Asian EFL Journal.

Accessed at: http://www.asian-efljournal. com/Litz_thesis.pdf.

Richards, J.C \& R. Schmidt, (Eds.) $4^{\text {th }}$ (2010). Longman Dictionary of Language Teaching \& Applied Linguistics. Edition. UK: Pearson Education Limited.

McDonough, J. \& C. Shaw. (1997). Materials and Methods in ELT. UK: Blackwell Publishers Ltd.

McGrath, I. (2013). Teaching Materials and the Roles of EFL/ESL Teachers: Practice and Theory. Bloomsbury.

McKay, S. (2013). Authenticity in the Language Teaching Curriculum. In C.A. Chapelle (Ed.), The Encyclopedia of Applied Linguistics (1-6). Blackwell Publishing Ltd.

Mukundan, J. (2007). Evaluation of English Language Textbooks: Some Important Issues for Consideration. Journal of NELTA, 12(1\&2), 80-4.

Mukundan, J., Hajimohammadi, R., Nimehchisalem, V. (2011). Developing an English Language Textbook Evaluation Checklist. Contemporary Issues in Education Research, 4(6), 21-28.

Mukundan, J. \& Rezvani Kalajahi, S.A. (2013). Evaluation of Malaysian English Language Teaching. International Journal of Education \& Literacy Studies, 1(1), 38-46. 
Learning. UK: Taylor \& Francis e-Library.

Nair, G.K.S., Rahim, R.A., Setia, R., Husin, N., \& Sabapathy, E., et.al. (2012). Malaysian Graduates English Adequacy in the Job Sector. Asian Social Science, 8(4), 143-147.

Nasiri, S. \& Ahmadi, E. (2011). Textbook Evaluation: A Retrospection Study. Journal of Academic and Applied Studies, 1(5), 9-17.

Nimehchisalem, V. \& Mukundan, J. (2015). Refinement of the English Language Teaching Textbook Evaluation Checklist. Pertanika Journal Social Science and Humanities, 23(4), 761-780.

Nunan, D. (2004). Task-Based Language Teaching. Cambridge: Cambridge University Press.

Oxford, R. (2001). Integrated Skills in the ESL/EFL Classroom. ESL Magazine, 6(1), 1-6.

Rahimpour, S. (2013). TEFL textbook evaluation. Proceeding of the Global Summit on Education, Kuala Lumpur, 1112 March 2013, 764-772.

Rahman, M.M. (2012). An Evaluation of English Writing Text at the preparatory Year, Najran University, Saudi Arabia. Academic Research International, 2(2), 706-715.

Richards, J.C. (2002). The Role of Textbooks in a Language Program. Accessed at: www.professorjackrichards.com

Roberts, J.T. (1996). Demystifying Materials Evaluation. System, 24(3), 375-389.

Rubdy, R. (2005). Selection of Materials. In B. Tomlinson (Ed.), Developing Materials for Language Teaching (37-57). London: Continuum.

Sarem, S.N., Hamidi, H., \& Mahmoudie, R. (2013). A Critical Look at Textbook Evaluation: A Case Study of Evaluating an ESP Course-Book: English for International Tourism. International Research Journal of Applied and Basic Sciences, 4(2), 372-380.

Shah, S.K., Rafique, S., Shakir, A., \& Zahid, S. (2014). Textbook Evaluation of English for Academic Purposes by British Council. Research on Humanities and Social Sciences, 4(7), 104-114.

Sheldon, L.E. (1987). Introduction. In L. E. Sheldon (Ed.), ELT textbooks and materials: problems in evaluation and development (1-10). London: Modern English Publications.

Sheldon, L.E. (1988). Evaluating ELT Textbooks and Materials. ELT Journal, 42(4), 237-246.

Singh, M.K.M. (2014). Undergraduates' Perception of the English Language proficiency Courses at Tertiary Level. International Journal of Humanities and Social Science, 4(12), 185-190.

Tomlinson, B. (2003). Glossary of basic terms for materials development in language teaching. In B. Tomlinson (Ed.), Materials Development in Language Teaching (ix-xviii). Cambridge: Cambridge University Press.

Tomlinson, B. (2005). Materials Evaluation. In B. Tomlinson (Ed.), Developing Materials for Language Teaching (1536). London: Continuum.

Tomlinson, B. (2008). Language Acquisition and Language Learning Materials. In B. Tomlinson (Ed.), English Language Learning Materials: A Critical Review (3-13). London: Continuum.

Tomlinson, B. (2013). Humanizing the Coursebook. In B. Tomlinson (Ed.), $2^{\text {nd }}$ Ed. Developing Materials for Language Teaching (139-155). Bloomsbury Academic.

Tsiplakides, I. (2011). Selecting an English Coursebook: Theory and Practice. Theory and Practice in Language Studies, 1(7), 758-764.

Ur, P. (1999). A Course in Language Teaching: Practice and Theory. Cambridge: Cambridge University Press.

Williams, D. (1983). Developing Criteria for Textbook Evaluation. ELT Journal, 37(2), 251-255. 